\title{
Interactions between IGF-I, estrogen receptor- $\alpha(E R \alpha)$, and ER $\beta$ in regulating growth/apoptosis of MCF-7 human breast cancer cells
}

\author{
Rhone A Mendoza, Marlene I Enriquez, Sylvia M Mejia, Emily E Moody and Gudmundur Thordarson \\ Department of Biomedical Sciences, Center of Excellence in Cancer Research, Texas Tech University Health Sciences Center, Paul L Foster School of Medicine, \\ 5001 El Paso Drive, El Paso, Texas 79905, USA \\ (Correspondence should be addressed to G Thordarson who is now at the Department of Biological Sciences, University of Texas at El Paso, El Paso, Texas 79968, \\ USA; Email: gthordarson2@utep.edu)
}

\begin{abstract}
Understanding of the interactions between estradiol $\left(\mathrm{E}_{2}\right)$ and IGF-I is still incomplete. Cell lines derived from the MCF-7 breast cancer cells were generated with suppressed expression of the IGF-I receptor (IGF-IR), termed IGF-IR.low cells, by stable transfection using small interfering RNA (siRNA) expression vector. Vector for control cells carried sequence generating noninterfering RNA. Concomitant with reduction in the IGF-IR levels, the IGF-IR.low cells also showed a reduction in estrogen receptor $\alpha(E R \alpha)$ and progesterone receptor expressions, and an elevation in the expression of ER $\beta$. The number of the IGF-IR.low cells was reduced in response to IGF-I and human $\mathrm{GH}$ plus epidermal growth factor, but $\mathrm{E}_{2}$ did not cause an increase in the number of the IGF-IR.low cells compared to controls. The proliferation rate of IGF-IR.low cells was only reduced in response to $E_{2}$ compared to
\end{abstract}

controls, whereas their basal and hormone-stimulated apoptosis rate was increased. Phosphorylation of p38 mitogen-activated protein kinase (p38 MAPK) was increased in the IGF-IR.low cells after treatment with $\mathrm{E}_{2}$, without affecting control cells. Furthermore, phosphorylation of the tumor suppressor protein p53 was elevated in the IGF-IR.low cells compared to the controls. In conclusion, suppressing IGF-IR expression decreased the level of ER $\alpha$ but increased the level of ER $\beta$. Overall growth rate of the IGF-IR.low cells was reduced mostly through an increase in apoptosis without affecting proliferation substantially. We hypothesize that a decreased $\operatorname{ER} \alpha: \operatorname{ER} \beta$ ratio triggered a rapid phosphorylation of p38 MAPK, which in turn phosphorylated the p53 tumor suppressor and accelerated apoptosis rate.

Journal of Endocrinology (2011) 208, 1-9

\section{Introduction}

Estradiol $\left(\mathrm{E}_{2}\right)$ and insulin-like growth factor-I (IGF-I) interact closely to regulate growth of the breast epithelia (Kleinberg \& Ruan 2008) and these hormones also stimulate growth of the breast cancer cells (Lee et al. 1999) and affect mammary carcinogenesis in animal models (Thordarson et al. 2001, $2004 a, b)$. Much research has been carried out on the interactions between the $\mathrm{E}_{2}$ /estrogen receptor (ER) and the IGF-I/IGF-I receptor (IGF-IR) in the breast, but these interactions are still not fully understood, and they are likely to be multiple. However, we do know that mammary epithelial growth is rudimentary in mice lacking IGF-I expression and $\mathrm{E}_{2}$, even at high doses, cannot compensate for this lack of mammary epithelial development in the absence of IGF-I (Kleinberg et al. 2000). These results show that $\mathrm{E}_{2}$ depends on the presence of IGF-I to effect mammary development, but the $\mathrm{E}_{2}$ /ER also influences the activity of IGF-I by enhancing the expression of the IGF-IR (Stewart et al. 1990, Maor et al. 2006) and insulin receptor substrate 1 (Lee et al. 1999). The link between IGF-I and $\mathrm{E}_{2}$ in regulating breast development and breast carcinogenesis is wider in scope, and, in fact, extensive cross talk is well established between the $E R \alpha$ and receptor tyrosine kinases, including the IGF-IR and their signaling pathways (Sisci \& Surmacz 2007, Fagan \& Yee 2008). IGF-I causes activation (phosphorylation) of the ER and this ER activation does not require ER-ligand interaction but is mitogen-activated protein kinase (MAPK) dependent (Kato et al. 1995). In addition, the IGF-IR appears to be essential for the nongenomic, membrane-associated ER $\alpha$ activity (Song et al. 2004, 2010), although understanding of this interaction at the cell membrane is still incomplete. Most of the work on the interactions between the IGF-IR and the ER has involved ER $\alpha$. However, increasing evidence indicates that the interplay between the two subtypes of the ER, ER $\alpha$ and $E R \beta$, is fundamental for $E_{2}$ action. The distinctions and similarities between the ER $\alpha$ and ER $\beta$ in the breast and other tissues are being actively investigated. Nonetheless, we know that each receptor form has a unique transcriptional profile and transcriptional activities of the ER subtypes are affected by their interactions (Hall \& McDonnell 1999, Chang et al. 2006). Moreover, both $\mathrm{ER} \alpha$ and $\operatorname{ER} \beta$ are capable of associating with the cell membrane (Razandi et al. 2004, Pedram et al. 2006) and they 
have been reported to exert their effects via the MAPK pathway (Song et al. 2007, Hershberger et al. 2009). From these and other studies, it appears to be emerging that the ratio of the two subtypes may be the determining factor as to how the ERs regulate the different cellular functions (reviewed in Matthews \& Gustafsson (2003) and Heldring et al. (2007)). Therefore, the effects of the two ERs in the breast may differ substantially. In fact, increasing evidence now indicates that the ER $\alpha$ may be primarily associated with regulation of cell proliferation, while the $\mathrm{ER} \beta$ form has been linked with regulating cell apoptosis (Acconcia et al. 2005, Zhao et al. 2007, 2008, Hodges-Gallagher et al. 2008). It should be kept in mind that this distinction is probably oversimplified and how these two ERs influence cell functions will depend on physiological conditions and tissue types among other variations.

In this study, we have investigated the interactions of ER $\alpha$ and ER $\beta$ with the IGF-IR to regulate growth and apoptosis of the MCF-7 breast cancer cells.

\section{Materials and Methods}

\section{Cells}

The MCF-7 human breast cancer cell line was purchased from ATCC (Manassas, VA, USA) and maintained at $37^{\circ} \mathrm{C}$ in humidified air with $5 \% \mathrm{CO}_{2}$ in DME/F12 medium, without phenol red, containing 10\% fetal bovine serum (FBS) and $50 \mu \mathrm{g} / \mathrm{ml}$ gentamicin, which is the basic growth medium. For experimentation, the cells were plated in DME/F12 medium containing $10 \%$ FBS. After overnight culture, the medium was changed to serum-free, phenol-red-free DME/F12 medium containing trace elements and cultured for an additional $24 \mathrm{~h}$. The cells were then exposed to different treatments and for varying lengths of time, as indicated in the figure legends.

\section{Stable transfection of MCF-7 cells}

To reduce the expression of the IGF-IR, custom-made expression vectors capable of generating small doublestranded interfering RNA (siRNA) corresponding to a 21 nucleotide (nt) sequence of the human IGF-IR cDNA sequence (Ullrich et al. 1986) were purchased from InvivoGen (San Diego, CA, USA). The vector for transfecting control cells carried sequence generating noninterfering $21 \mathrm{nt}$ RNA (InvivoGen, San Diego, California, USA). For the transfections, MCF-7 cells were plated onto six-well plates at $\sim 60 \%$ confluency and incubated overnight in DME/F12 medium containing $10 \% \mathrm{FBS}$ and $50 \mu \mathrm{g} / \mathrm{ml}$ gentamicin. Next morning, the medium was changed to serum-free DME/ F12 medium without antibiotics. Transfection was carried out using the LipofectAMINE PLUS method (Invitrogen) according to the manufacturer's instructions. Medium containing 10\% FBS was added $24 \mathrm{~h}$ after the transfection and cells were cultured for $48 \mathrm{~h}$, when a medium containing the selectable marker (hygromycin, HyClone, Logan, UT, USA) was applied. Colonies that grew were isolated using clone rings and maintained in medium containing 10\% FBS and hygromycin $(50 \mu \mathrm{g} / \mathrm{ml})$. Cells transfected with vector carrying noninterfering 21 nt RNA were also cloned, maintained in the same medium, and used as controls.

\section{Cell number studies}

To study the growth characteristics of the IGF-IR-deficient cells (IGF-IR.low) they were plated into 24-well culture plates in the basic growth medium at the density of 50000 cells/well. After overnight incubation, the medium was changed to serum-free, phenol-red-free medium and cells were cultured for an additional $24 \mathrm{~h}$, when they were treated. Control cells, transfected with noninterfering small RNA, were treated in parallel with the IGF-IR.low cells. Treatments were continued from 1 to 10 days and media were replenished every other day. Total DNA content of the cells was measured to assess increase/decrease in cell number using the diaminobenzoic acid method (Hinegardner 1971).

\section{5-Bromo-2'-deoxyuridine incorporation}

The proliferation rate of the cultured cells was measured using an ELISA kit based on 5-bromo-2'-deoxyuridine (BrdU) incorporation (Roche Applied Science). The cells were plated onto 96-well plates in 10\% FBS and incubated for $24 \mathrm{~h}$ and then serum starved for an additional $24 \mathrm{~h}$. Subsequently, the cells were exposed to the different treatment media as specified in the figure legends and incubated overnight. The following morning, fresh treatment media containing $10 \mu \mathrm{M}$ BrdU were added and cells were incubated for an additional $90 \mathrm{~min}$, at which point the cultures were terminated and the BrdU incorporation was measured according to the manufacturer's instructions.

\section{Apoptosis assay}

The rate of apoptosis was measured using an ELISA kit (M30-Apoptosense, Peviva, Bromma, Sweden). This assay is based on caspase cleavage of cytokeratin 18, which exposes a neo-epitope on the cleaved protein. A specific antibody (M30) was generated to this neo-epitope, which was used in this assay (Hagg et al. 2002). The cells were plated onto 96-well plates in $10 \% \mathrm{FBS}$ and incubated for $24 \mathrm{~h}$ and then serum starved for an additional $24 \mathrm{~h}$. Subsequently, the cells were exposed to the different treatment media and incubated overnight. For each cell line in all experiments, replicate wells were treated with $60 \mu \mathrm{m}$ Roscovitine to assess the total cell number at the time of treatment. This concentration of Roscovitine will cause complete apoptosis of the cells (Schutte et al. 2004). At the end of the incubation period, the cells were exposed to $10 \%$ NP-40, final concentration $0.5 \%$, and lysed for $5 \mathrm{~min}$ on a rotatory shaker. The assays of the cell lysates were carried out according to the manufacturer's instructions. 


\section{Western blotting}

The expressions of the IGF-IR, ER $\alpha, \mathrm{ER} \beta$, progesterone receptor (PR), total p38 MAPK, and total p53 tumor suppressor protein (p53) were assessed using western blotting. The cells were cultured in 60 or $100 \mathrm{~mm}$ diameter culture dishes in the basic growth medium at the density of $4 \cdot 0 \times 10^{6}$ and $7.5 \times 10^{6}$ cells/dish respectively. After an overnight incubation, the medium was changed to serumfree and the cells were cultured for an additional $24 \mathrm{~h}$. The cells were then scraped and lysed, total protein was extracted, and protein concentrations were measured using the BCA protein assay (Pierce, Rockford, IL, USA). After electrophoresis, the protein was transferred to PVDF membrane for western blot analysis using chemiluminescent detection. The ER $\alpha$-specific antibody was from Thermo Fisher Scientific (Fremont, CA, USA), and antibodies to the IGF-IR ( $\beta$-subunit), ER $\beta$, PR, total p38 MAPK, total p53, and $\beta$-actin were obtained from Santa Cruz Biotechnology (Santa Cruz, CA, USA). Chemiluminescent detections and densitometric quantifications were performed using Kodak Image Station 2000R (Eastman Kodak Company), and the results for each protein are expressed as a ratio of $\beta$-actin expression. For each quantitative analysis, the results from two or three cell lines in each group (controls, IGF-IR.low) were pooled. The total number of observations is indicated in the figure legends for all western blots.

ELISA assays for measuring phosphorylation of $p 38 \mathrm{MAPK}$ and p53 tumor suppressor protein

The activity (phosphorylation) of p38 MAPK and p53 was measured using ELISA kits from R\&D Systems, Inc. (Minneapolis, MN, USA) and SA Biosciences (Frederick, $\mathrm{MD}$, USA) respectively. For these assays, the cells were cultured in $60 \mathrm{~mm}$ diameter culture plates as described above. After an overnight serum starvation, media were changed to treatment or control (containing vehicle) media and the cells were incubated for $10 \mathrm{~min}$, then the cells were washed in ice-cold PBS and harvested by scraping in ice-cold PBS. After centrifugation for $5 \mathrm{~min}$ at $2000 \mathrm{~g}$, the supernatant was discarded and the pelleted cells were stored at $-80{ }^{\circ} \mathrm{C}$ until they were lysed for the assays. The cells were lysed and the assays were carried out according to the manufacturer's instructions. Total protein concentrations (BCA, Pierce) of the cell lysates were used for normalizing the assay results.

\section{Statistical analysis}

Data are presented as means \pm S.E.M. of 3-8 observations. Significant levels between the groups were determined using ANOVA and Student-Newman-Keuls post hoc test. Differences between the groups were considered significant when $P$ values of $<0 \cdot 05$ were obtained.

\section{Results}

Transfection with the IGF-IR-siRNA vector

Several MCF-7 clones transfected with plasmid carrying the IGF-IR-siRNA sequence and controls transfected with plasmid carrying the small noninterfering sequence were isolated using clone rings. Some of the IGF-IR-siRNA clones showed severe reduction in the IGF-IR expression and growth rate, and were not viable in long-term cultures, but three clones, termed IGF-IR.low1-3, were viable and showed a significant reduction in the expression of IGF-IR (Fig. 1A and B). The behavior of these IGF-IR.low cloned cells was undistinguishable in culture and they were used in all subsequent experimentations. At least two IGF-IR.low cell lines and two cloned control cell lines were tested in replicates in all experiments.
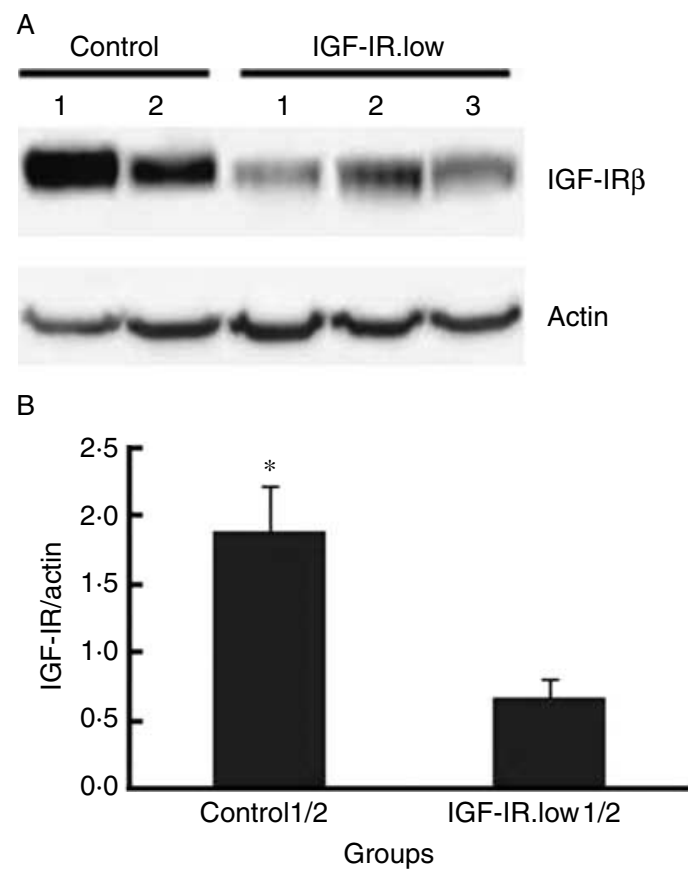

Figure 1 Western blot analysis showing the expression of the insulin-like growth factor-I receptor (IGF-IR) and actin (internal control) in cloned MCF-7 cells stably transfected with a vector producing a small interfering RNA (siRNA) to the IGF-IR (IGF-IR.low) and control cells transfected with a vector producing an inert small RNA of the same size as the IGF-IR-siRNA. The cells were plated onto $100 \mathrm{~mm}$ culture dishes in DME/F12 medium containing $10 \%$ FBS and cultured for $24 \mathrm{~h}$, then cells were harvested and lysed, and total protein was extracted and analyzed. For the controls, two different cloned cells lines are shown (control1, 2), and three different IGF-IR.low cell lines (IGF-IR.low1-3) are shown (A). The IGF-IR protein levels were quantified using densitometric analysis and the results are expressed as IGF-IR/ $\beta$-actin ratio. Each bar represents the mean \pm S.E.M. of five (controls) and six (IGF-IR.low) replicates. Asterisk indicates significant differences between controls and IGF-IR. low cells, $P<0 \cdot 05$ (B). 


\section{Cell number studies}

Figure 2 shows the overall net cell number changes, as assessed by total DNA content, when the cells were cultured for 10 days in media with $1 \times 10^{-7} \mathrm{M} \mathrm{E}_{2}, 50 \mathrm{ng} / \mathrm{ml} \mathrm{IGF-I \text {,and }}$ $500 \mathrm{ng} / \mathrm{ml}$ human $\mathrm{GH}$ plus $10 \mathrm{ng} / \mathrm{ml}$ epidermal growth factor (EGF). Administration of IGF-I still elicited cell
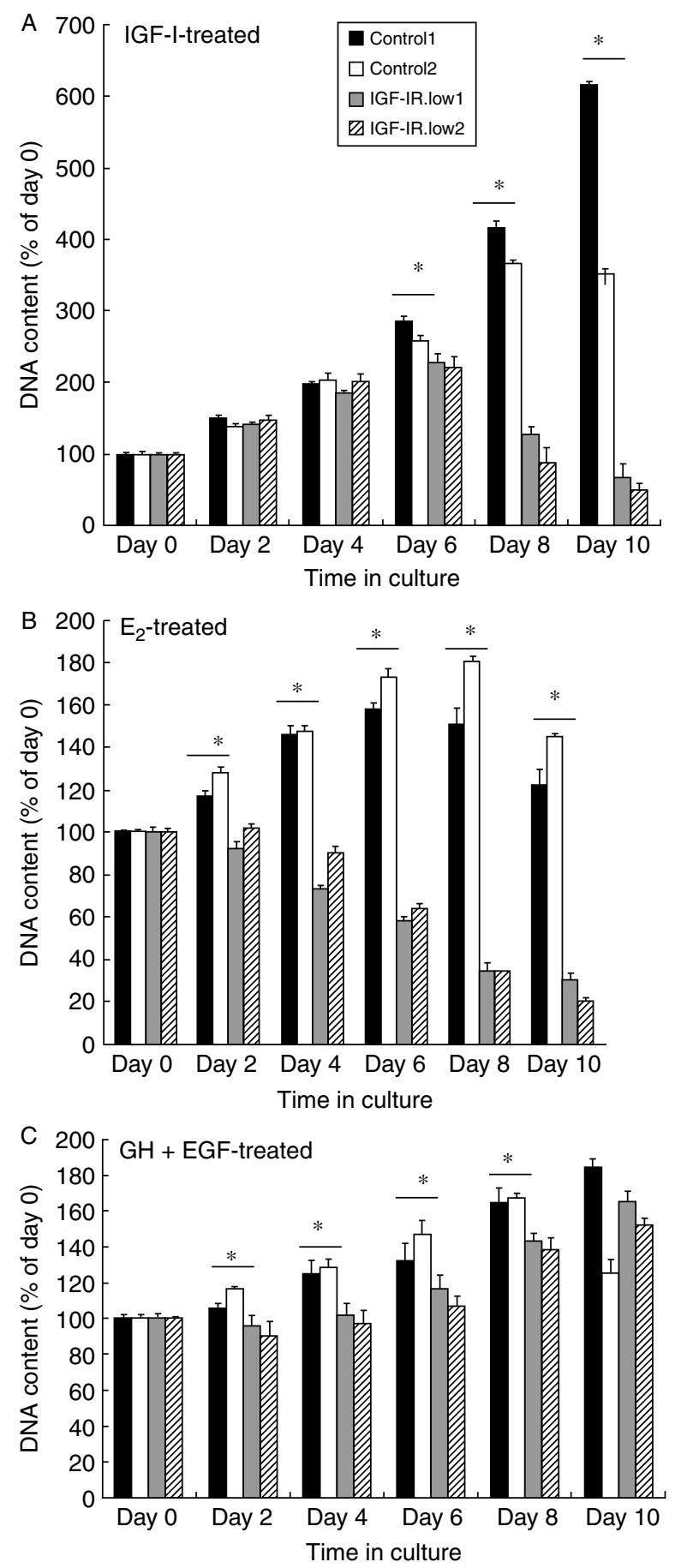

Journal of Endocrinology (2011) 208, 1-9 number increase in IGF-IR.low cells, but the responses were reduced compared to controls after $\sim 5$ days in culture, whereas the controls continue to show cell number increase throughout the culture period (Fig. 2A). $\mathrm{E}_{2}$ was a very poor stimulator of cell number increase in the IGF-IR.low cells, and, in fact, no net increase in the cell number was observed at any time during the 10-day time course, but the cell number from the second day of culture continued to decline for the remainder of the culture period (Fig. 2B). When the cells were cultured in the presence of GH plus EGF, the number of IGF-IR.low cells was reduced compared to the controls, particularly at the early stages of the time course. However, the characteristics of the rise in the cell number of IGF-IR.low cells and that of the controls were similar, with a continuous net increase throughout the culture period and, on the last day of culture, no significant difference was observed between the two groups in the number of cells (Fig. 2C).

\section{BrdU incorporation}

The proliferation rate of the cells was measured using BrdU uptake. Each hormone treatment (either $\mathrm{E}_{2}$, IGF-I, or GH plus EGF) increased cell proliferation in both control cells and IGF-IR.low cells compared to untreated cells. However, only $E_{2}$ showed reduced efficacy in the IGF-IR.low cells, whereas IGF-I and the combined treatment of GH and EGF were equally effective in the controls and the IGF-IR.low cells (Fig. 3).

\section{Apoptosis}

The rate of apoptosis of the IGF-IR.low cells was approximately doubled compared to the controls. This was seen regardless of whether the cells were untreated or after treatment with $\mathrm{E}_{2}$, IGF-I, or GH plus EGF. However, the apoptosis rate was significantly reduced after treatments with IGF-I and GH plus EGF in both IGF-IR. low cells and controls compared to the same cells untreated, but $\mathrm{E}_{2}$ did not lower death rate in neither control cells nor IGF-IR.low cells (Fig. 4).

Figure 2 Growth response of MCF-7 cells stably transfected with a vector producing a small interfering RNA (siRNA) to the insulin-like growth factor-I receptor (IGF-IR.low) and control cells transfected with a vector producing an inert small RNA of the same size as the IGF-IR-siRNA. The cells were plated onto 24-well plates in DME/F12 medium containing 10\% FBS and incubated for $24 \mathrm{~h}$. The media were then changed to serum-free and incubated for an additional $24 \mathrm{~h}$ and then treated with (A) $50 \mathrm{ng} / \mathrm{ml} \mathrm{IGF-I,}$ (B) $10^{-7}$ M $17 \beta$-estradiol $\left(E_{2}\right)$, and (C) $500 \mathrm{ng} / \mathrm{ml}$ human $\mathrm{GH}$ plus $10 \mathrm{ng} / \mathrm{ml}$ epidermal growth factor (EGF). The cultures were continued for 10 days and the media were replenished every other day, at the same time of day. Four replicate wells were terminated at each time point to establish the growth rate over the 10-day period. At the end of the culture period, total DNA was measured to assess cell number. Each bar represents mean \pm S.E.M. for four replicate wells. Asterisks indicate significant differences between the controls and IGF-IR. low cells, $P<0 \cdot 05$. 


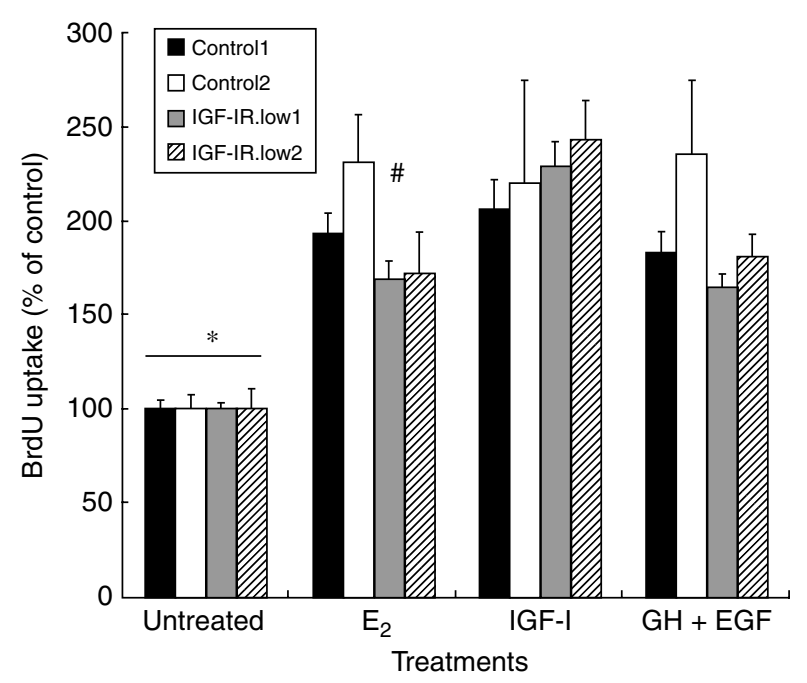

Figure 3 The proliferation rates of the cultured MCF-7 cells stably transfected with a vector producing a small interfering RNA (siRNA) to the insulin-like growth factor-I receptor (IGF-IR.low) and controls were measured using an ELISA kit based on 5-bromo-2'-

deoxyuridine (BrdU) incorporation. The cells were plated onto 96-well plates in 10\% FBS and incubated for $24 \mathrm{~h}$ and then serum starved for an additional 24-h, followed by treatments with $50 \mathrm{ng} / \mathrm{ml} \mathrm{IGF-I,} 10^{-7} \mathrm{M} 17 \beta$-estradiol $\left(E_{2}\right)$, and $500 \mathrm{ng} / \mathrm{ml}$ human $\mathrm{GH}$ plus $10 \mathrm{ng} / \mathrm{ml}$ epidermal growth factor (EGF) or vehicle (untreated), and the cells were incubated overnight. The following morning, fresh treatment media containing $10 \mu \mathrm{M}$ BrdU were added and the cells were incubated for an additional $90 \mathrm{~min}$, when cultures were terminated and BrdU incorporation was measured. Each bar represents mean \pm s.E.M. of eight replicate wells. Asterisk indicates significantly different from all hormone-treated cells, (\#) indicates significantly lower than control cells receiving the same treatment, $P<0 \cdot 05$.

\section{Expression of the $E R \alpha, E R \beta$, and $P R$}

Lowering the expression of the IGF-IR caused a significant reduction in the ER $\alpha$ protein level when assessed by western blot analysis. Concomitant with the reduction in the ER $\alpha$ expression was a decrease in both the PR-A and PR-B expressions. However, the reverse was seen for the expression of the ER $\beta$ where protein level was increased in the IGF-IR.low cells compared to control cells (Fig. 5A and B).

\section{Phosphorylation of p 38 MAPK and p53 tumor suppressor}

When the IGF-IR.low cells were treated with $\mathrm{E}_{2}$ for $10 \mathrm{~min}$, a significant increase was observed in p38 MAPK phosphorylation compared to the untreated IGF-IR.low cells and treated and untreated control cells (Fig. 6A). This increase in p38 MAPK phosphorylation was not caused by a higher level of total p38 MAPK protein in the IGF-IR.low cells as demonstrated by western blot analysis (Fig. 6B). Moreover, the phosphorylated p38 MAPK:p38 MAPK total ratio was only slightly (20\%) higher in the untreated IGF-IR.low cells compared to the untreated controls (not shown), further demonstrating that the total protein level of p38 was not affected in the IGF-IR.low cells and strongly indicating that the $\mathrm{E}_{2}$ treatment caused the increase in the p38 MAPK activity. No difference was seen in the phosphorylation levels of p38 MAPK in untreated and $\mathrm{E}_{2}$-treated control cells (Fig. 6A).

To assess the effects of reduction in the expression of IGF-IR on the phosphorylation (activation) of p53 tumor suppressor protein, the phosphorylation levels of Ser46 on p53 was measured using a specific ELISA assay. As shown in Fig. 6C, the basal phosphorylation level of p53 was significantly increased in the IGF-IR.low cells when compared to control cells. As shown in Fig. 6D, the increased p53 phosphorylation level in the IGF-IR.low cells was not because of a higher level of total p53 protein in these cells.

\section{Discussion}

In an effort to better understand the interactions between IGF-I and $E_{2}$ in regulating the growth of ER-positive breast cancer cells, we generated cell lines expressing low levels of the IGF-IR. Cloned cells with undetectable or severely

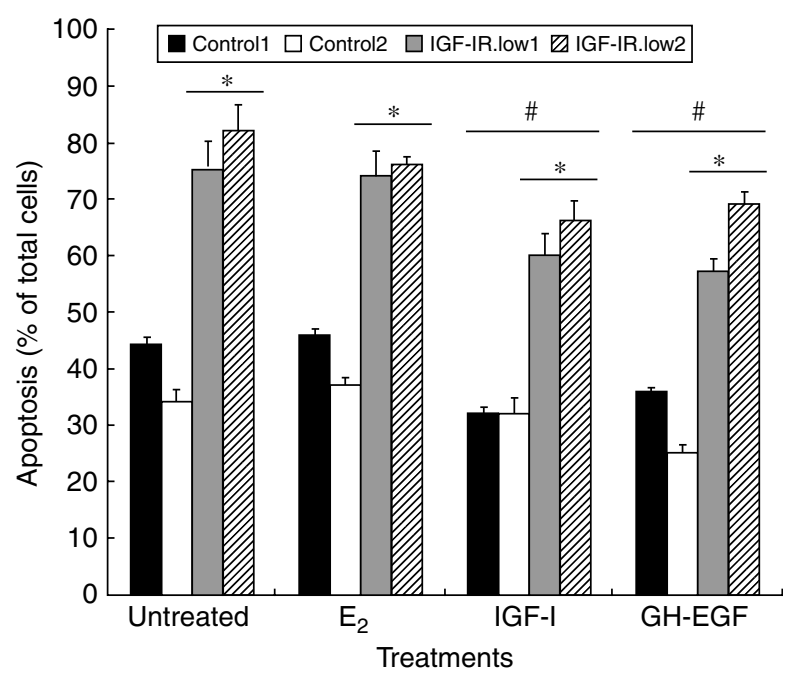

Figure 4 The rate of apoptosis of the cultured MCF-7 cells stably transfected with a vector producing a small interfering RNA (siRNA) to the insulin-like growth factor-I receptor (IGF-IR.low) and control cells. ELISA kit based on neo-epitope exposure after caspasecleaved cytokeratin 18 was used to measure the rate of apoptosis. The cells were plated onto 96-well plates in 10\% FBS and incubated for $24 \mathrm{~h}$ and then serum starved for an additional $24 \mathrm{~h}$. The medium was then changed to treatment media consisting of $50 \mathrm{ng} / \mathrm{ml} \mathrm{IGF-I,}$ $10^{-7} \mathrm{M} 17 \beta$-estradiol $\left(\mathrm{E}_{2}\right)$, and $500 \mathrm{ng} / \mathrm{ml}$ human $\mathrm{GH}$ plus $10 \mathrm{ng} / \mathrm{ml}$ epidermal growth factor (EGF) or vehicle (untreated) and the cells were incubated overnight. The following morning, the cells were exposed to NP-40, final concentration $0 \cdot 5 \%$, and lysed for $5 \mathrm{~min}$ on a rotatory shaker. Assays of the cell lysates were carried out according to the manufacturer's instructions. Each bar represents mean \pm S.E.M. for five to eight replicate wells. Asterisk indicates significantly different from control cells with the same treatment; $(\#)$ indicates significantly different from the same cells when untreated, $P<0 \cdot 05$. 

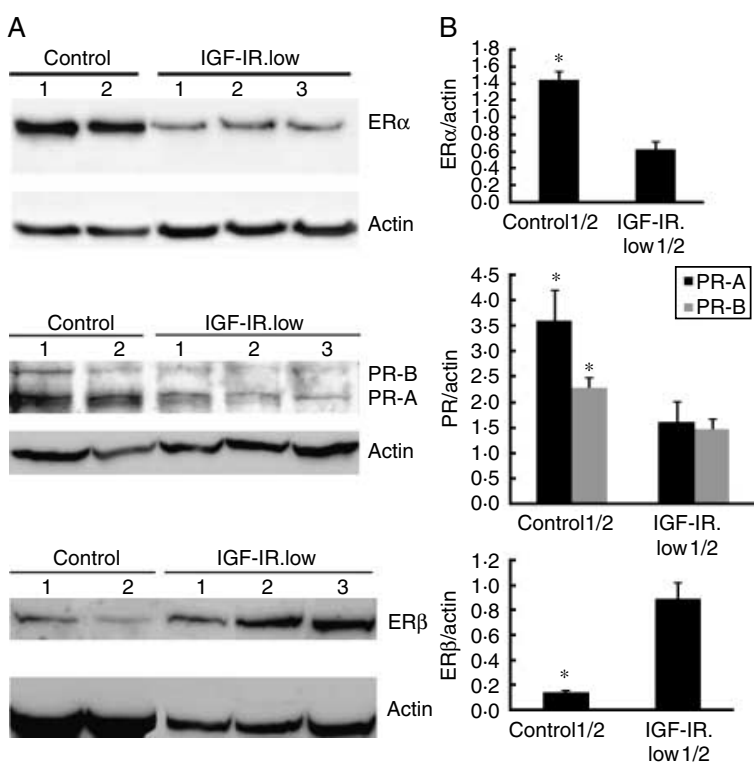

Figure 5 Western blot analysis showing expression of the estrogen receptor- $\alpha(E R \alpha)$, the progesterone receptor $(P R)$, and the $E R \beta$ in cloned MCF-7 cells stably transfected with a vector producing a small interfering RNA (siRNA) to the insulin-like growth factor-I receptor (IGF-IR.low) and control cells transfected with a vector producing an inert small RNA of the same size as the IGF-IR-siRNA. $\beta$-Actin was used as an internal control. Cells were plated onto $100 \mathrm{~mm}$ culture dishes in DME/F12 medium containing 10\% FBS and cultured for $24 \mathrm{~h}$, followed by a $24 \mathrm{~h}$ serum starvation. The cells were then harvested and lysed, and total protein was extracted and total protein concentration of the lysate was measured before western blot analysis (A). Densitometry was used for quantification of the receptor protein levels and the results are shown as ratios of $\beta$-actin expression. Each bar represents mean \pm s.E.M. of four (controls) and six (IGF-IR.low) replicates. Asterisks indicate significant differences between the controls and IGF-IR. low cells, $P<0 \cdot 05$ (B).

reduced expression of the IGF-IR were not viable after a few passages as mentioned above, which corroborates with previous report in which MCF-7 cells with $>90 \%$ reduction in the IGF-IR expression were found to enter quiescence and were not suitable for experimentation (Bradley et al. 2008). Therefore, although the expression of the IGF-IR was not completely eliminated in the IGF-IR.low cells, a reduced expression caused significant growth retardation in response to IGF-I compared to controls after day 5 of culture. These findings demonstrate that some IGF-IR activity was present and necessary for survival of these breast cancer cells and also reveal the fundamental importance of the IGF system in growth regulation of ER-positive breast cancer cells. The cells with significantly reduced expression of the IGF-IR also showed a reduced overall growth rate when stimulated with $\mathrm{E}_{2}$, and $\mathrm{GH}$ plus EGF, although they retained the growth characteristics of the controls when they were treated with $\mathrm{GH}$ plus EGF in that they continued to grow during the 10-day time course. Further characterization of this growth inhibition revealed that the cell proliferation rate was not affected in the IGF-IR.low cells when they were treated with IGF-I or GH plus EGF compared to controls. However, although $\mathrm{E}_{2}$ significantly increased the proliferation rate of the IGF-IR.low cells, this increase was significantly less than that of controls treated with $\mathrm{E}_{2}$. More dramatic effects were seen on the rate of apoptosis in the IGF-IR.low cells, where the apoptosis rate was significantly higher regardless of whether the cells were untreated or treated with mitogens compared to controls. The severe growth retardation of the IGF-IR.low cells when they were treated with $\mathrm{E}_{2}$ was unexpected, but
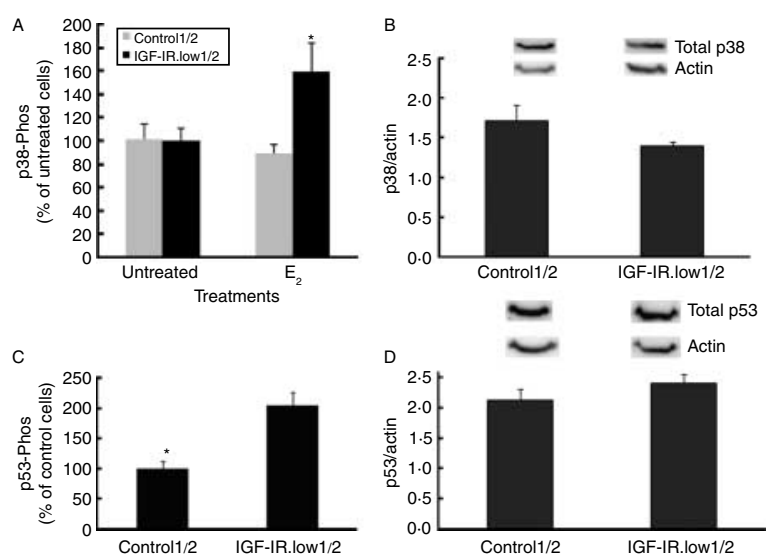

Figure 6 The activity (phosphorylation) of p38 mitogen-activated protein kinase (p38 MAPK). MCF-7 cells stably transfected with a vector producing a small interfering RNA (siRNA) to the insulin-like growth factor-I receptor (IGF-IR.low) and control cells transfected with a vector producing an inert small RNA of the same size as the IGF-IR-siRNA were cultured in $60 \mathrm{~mm}$ culture plates in 10\% FBS. After overnight serum starvation, the cells were either left untreated or treated with $10^{-7} \mathrm{M} 17 \beta$-estradiol $\left(E_{2}\right)$ and the incubation continued for $10 \mathrm{~min}$, then the cells were washed in ice-cold PBS and harvested by scraping in ice-cold PBS. After centrifugation for $5 \mathrm{~min}$, the cells were lysed and the assays were carried out according to the manufacturer's instructions. Total protein concentrations of the cell lysates were used for normalizing the assay results. Each bar represents mean \pm s.E.M. for three replicate plates. Asterisk indicates significantly higher than all other groups, $P<0.05$ (A). To determine the total basal protein levels of the p38 MAPK, western blot analysis was carried out on samples from identical cultures to that shown in (A) for untreated cells and the results were quantified using densitometric analysis. Results are expressed as p38 MAPK/ $\beta$-actin ratio. Each bar represents mean \pm s.E.M. of four (controls) and five (IGF-IR.low) replicates (B). The activity (phosphorylation) of the p53 tumor suppressor protein was measured using an ELISA assay. The IGF-IR. low cells and control cells were plated onto $60 \mathrm{~mm}$ culture plates in $10 \% \mathrm{FBS}$ and incubated overnight, followed by $24 \mathrm{~h}$ serum starvation. Fresh serum-free medium was applied and the incubation continued for $10 \mathrm{~min}$, then the cells were washed in ice-cold PBS and harvested by scraping in ice-cold PBS and assayed for p53 phosphorylation. Each bar represents mean \pm s.E.M. for three replicate plates. Asterisk indicates significantly different from the control cells, $P<0 \cdot 05$ (C). The total protein expression levels of $\mathrm{p} 53$ were determined using western blot analysis and densitometric quantification from cultures identical to those described in $(\mathrm{C})$. The results are expressed as p53/ $\beta$-actin ratio. Each bar represents mean \pm S.E.M. of five (controls) and five (IGF-IR.low) replicates (D). 
when we assessed the expression levels of ER $\alpha$ in these cells, we found that it was substantially reduced compared to controls. By contrast, the IGF-IR.low cells showed a significant increase in the expression of $\mathrm{ER} \beta$. ER $\alpha$ has been shown to be associated with the IGF-IR at the plasma membrane and this association appears to be essential for the nongenomic, fast-acting activity of the receptor (Song et al. 2004, 2010). This ER $\alpha$ activity is mediated through the extracellular signal-regulated kinase (ERK), a pathway commonly associated with enhanced cell proliferation in breast cancers (Santen et al. 2002). Much less is known about how the ER $\beta$ affects cell function and, in particular, the function of breast cancer cells. However, we do know that deletion of the ERS2 gene does not cause severe disruption of mammary gland development in mice (Krege et al. 1998, Forster et al. 2002), indicating an insignificant role of ER $\beta$ in the breast. Nonetheless, growing evidence is now emerging which disputes this conclusion in that the balance between $\mathrm{ER} \alpha$ and $\mathrm{ER} \beta$ expression may be of fundamental importance for normal estrogen function in the breast and other tissues that are regulated by estrogen. For example, the ER $\alpha: \operatorname{ER} \beta$ ratio is elevated in proliferative preinvasive mammary tumors compared to normal tissues (Roger et al. 2001), and breast cancer resistance to tamoxifen treatment has been correlated with a reduction in ER $\beta$ levels (Hopp et al. 2004). In addition, it is now known that ER $\beta$ modulates the activity of $\mathrm{ER} \alpha$ at the transcriptional level, both acting directly on the estrogen response element (ERE) at the DNA (Klinge 2001, Chang et al. 2006), and indirectly through interaction with other transcription factors such as activating protein-1 (AP-1) and stimulating protein-1 (SP-1) where ER $\beta$ frequently displays opposite effects to ER $\alpha$ (Paech et al. 1997, Pettersson et al. 2000, Liu et al. 2002, Saville et al. 2002, Lindberg et al. 2003). In addition, $E R \beta$ is active at the plasma membrane, causing fast-acting, nongenomic effects. Earlier studies showed that transfecting Chinese hamster ovary cells with ER $\beta$ caused a rapid activation of the c-Jun $\mathrm{N}$-terminal kinase (JNK) upon estrogen administration, whereas transfecting the cells with the ER $\alpha$ had inhibitory effects on JNK activity (Razandi et al. 1999). More recently, it was shown that overexpression of ER $\beta$ in HeLa cells that do not naturally express the receptor causes a rapid induction of p38 MAPK activation upon $\mathrm{E}_{2}$ administration and an increase in the rate of apoptosis (Acconcia et al. 2005). This group of investigators also demonstrated that this fast-acting $\mathrm{E}_{2}$ activity through the $\operatorname{ER} \beta$ is dependent on palmitoylation of the receptor and membrane association (Galluzzo et al. 2007). Therefore, it appears that the nongenomic effects of the two ERs may have opposite effects to regulate cell growth, where the ER $\alpha$ is mainly involved with cell proliferation via the ERK and possible other growth regulatory pathways, whereas ER $\beta$ seems to be more important for the induction of apoptosis acting mostly through the p38 MAPK. Opposite effects of ERK and p38 MAPK were demonstrated over a decade ago, where p38 MAPK was associated with apoptosis and ERK with proliferation (Xia et al. 1995), and since then a number of studies have confirmed the apoptotic activity of p38 MAPK and its possible role in tumor suppression (reviewed in Bulavin \& Fornace (2004)). We have demonstrated in this study, using MCF-7 breast cancer cells, that reduction in the expression of IGF-IR disturbed the balance between ER $\alpha$ and $\operatorname{ER} \beta$ to favor a reduction in the $\operatorname{ER} \alpha: \operatorname{ER} \beta$ ratio. Furthermore, this reduction in the $\operatorname{ER} \alpha: \operatorname{ER} \beta$ ratio prevented the $E_{2}$-stimulated net growth of the cells, significantly reduced the rate of proliferation in response to $E_{2}$, and caused a sharp increase in the apoptosis rate of these cells. We also found that p38 MAPK in the IGF-IR.low cells was rapidly (within $10 \mathrm{~min}$ ) phosphorylated in response to $\mathrm{E}_{2}$ treatment and these cells also showed an increase in the basal phosphorylation levels of the p53 tumor suppression protein. The concomitant phosphorylation of the p38 MAPK and the p53 tumor suppressor protein is significant because p53 is an important substrate for the p38 MAPK (Bulavin et al. 1999). Based on these findings, we propose that the reduction in the IGF-IR expression tilts the ER $\alpha$ :ER $\beta$ balance by decreasing ER $\alpha$ expression while increasing ER $\beta$ expression, causing an increase in the phosphorylation of p38 MAPK, which in turn elevates p53 activation, leading to apoptosis. How the IGF-IR orchestrates this chain of events at the plasma membrane is not known. No association has been established between ER $\beta$ and IGF-IR. Yet, the fast-acting ER $\alpha$ activity has been connected with IGF-IR (Song et al. 2004, 2010) and, therefore, it is not unlikely that both $\operatorname{ER} \alpha$ and $\operatorname{ER} \beta$ interact with IGF-IR at the cell membrane to regulate cell growth. It is also possible that the reduction in IGF-IR activity and the accompanying reduction in ER $\alpha$ expression facilitated the activation of the signaling pathways that induce apoptosis, where the elevation in ER $\beta$ expression and $\mathrm{p} 38$ MAPK phosphorylation play key roles. However, it should be pointed out that the data presented in this study are correlative and it still has to be determined directly whether the altered $\mathrm{ER} \alpha / \mathrm{ER} \beta$ ration is the event triggering p38 MAPK phosphorylation and p53 activation. The mechanism is probably complicated and may involve the activation of other receptors and/or signaling pathways. Clearly, more work is needed to better understand how the two ERs interact with the IGF-IR at the cell membrane to regulate proliferation and apoptosis in breast cancer.

\section{Declaration of interest}

The authors declare that there is no conflict of interest that could be perceived as prejudicing the impartiality of the research reported.

\section{Funding}

This research was generously supported by grants from the Laura W Bush Institute for Women's Health-Permian Basin and the National Institutes of Health/National Cancer Institute R03CA128067 and R03CA128067-02S1 awarded to $\mathrm{G} T$. 


\section{Acknowledgements}

We thank Edward Jin for providing many of the antibodies for this study and for useful discussions.

\section{References}

Acconcia F, Totta P, Ogawa S, Cardillo I, Inoue S, Leone S, Trentalance A, Muramatsu M \& Marino M 2005 Survival versus apoptotic 17 $\beta$-estradiol effect: role of ER $\alpha$ and ER $\beta$ activated non-genomic signaling. Journal of Cellular Physiology 203 195-201. (doi:10.1002/jcp.20219)

Bradley LM, Gierthy JF \& Pentecost BT 2008 Role of insulin-like growth factor system on an estrogen-dependent cancer phenotype in the MCF-7 human breast cancer cell line. Journal of Steroid Biochemistry and Molecular Biology 109 186-196. (doi:10.1016/j.jsbmb.2007.10.006)

Bulavin DV \& Fornace AJ Jr 2004 p38 MAP kinase's emerging role as a tumor suppressor. Advances in Cancer Research 92 95-118. (doi:10.1016/S0065230X(04)92005-2)

Bulavin DV, Saito S, Hollander MC, Sakaguchi K, Anderson CW, Appella E \& Fornace A Jr 1999 Phosphorylation of human p53 by p38 kinase coordinates $\mathrm{N}$-terminal phosphorylation and apoptosis in response to UV radiation. EMBO Journal 18 6845-6854. (doi:10.1093/emboj/18.23.6845)

Chang EC, Frasor J, Komm B \& Katzenellenbogen BS 2006 Impact of estrogen receptor $\beta$ on gene networks regulated by estrogen receptor $\alpha$ in breast cancer cells. Endocrinology 147 4831-4842. (doi:10.1210/en. 2006-0563)

Fagan DH \& Yee D 2008 Crosstalk between IGF1R and estrogen receptor signaling in breast cancer. Journal of Mammary Gland Biology and Neoplasia 13 423-429. (doi:10.1007/s10911-008-9098-0)

Forster C, Makela S, Warri A, Kietz S, Becker D, Hultenby K, Warner M \& Gustafsson J-A 2002 Involvement of estrogen receptor $\beta$ in terminal differentiation of mammary gland epithelium. PNAS 99 15578-15583. (doi:10.1073/pnas.192561299)

Galluzzo P, Caiazza F, Moreno S \& Marino M 2007 Role of ER $\beta$ palmitoylation in the inhibition of human colon cancer cell proliferation. Endocrine-Related Cancer 14 153-167. (doi:10.1677/ERC-06-0020)

Hagg M, Biven K, Ueno T, Rydlander L, Bjorklund P, Wiman KG, Shoshan M \& Linder S 2002 A novel high-through-put assay for screening of pro-apoptotic drugs. Investigational New Drugs 20 253-259. (doi:10.1023/A:1016249728664)

Hall JM \& McDonnell DP 1999 The estrogen receptor $\beta$-isoform (ER $\beta$ ) of the human estrogen receptor modulates $\operatorname{ER} \alpha$ transcriptional activity and is a key regulator of the cellular response to estrogens and antiestrogens. Endocrinology 140 5566-5578. (doi:10.1210/en.140.12.5566)

Heldring N, Pike A, Andersson S, Matthews J, Cheng G, Hartman J, Tujague M, Strom A, Treuter E, Warner M et al. 2007 Estrogen receptors: how do they signal and what are their targets. Physiological Reviews $\mathbf{8 7}$ 905-931. (doi:10.1152/physrev.00026.2006)

Hershberger PA, Stabile LP, Kanterewicz B, Rothstein ME, Gubish CT, Land S, Shuai Y, Siegfried JM \& Nichols M 2009 Estrogen receptor beta $(E R \beta)$ subtype-specific ligands increase transcription, p44/p42 mitogen activated protein kinase (MAPK) activation and growth in human non-small cell lung cancer cells. Journal of Steroid Biochemistry and Molecular Biology 116 102-109. (doi:10.1016/j.jsbmb.2009.05.004)

Hinegardner RT 1971 An improved fluorometric assay for DNA. Analytical Biochemistry 39 197-201. (doi:10.1016/0003-2697(71)90476-3)

Hodges-Gallagher L, Valentine CD, El Bader S \& Kushner PJ 2008 Estrogen receptor beta increases the efficacy of antiestrogens by effects on apoptosis and cell cycling in breast cancer cells. Breast Cancer Research and Treatment 109 241-250. (doi:10.1007/s10549-007-9640-6)

Hopp TA, Weiss HL, Parra IS, Cui Y, Osborne CK \& Fuqua SAW 2004 Low levels of estrogen receptor $\beta$ protein predict resistance to tamoxifen therapy in breast cancer. Clinical Cancer Research 10 7490-7499. (doi:10.1158/10780432.CCR-04-1114)
Kato S, Endoh H, Masuhiro Y, Kitamoto T, Uchiyama S, Sasaki H, Masushige S, Gotoh Y, Nishida E, Kawashima H et al. 1995 Activation of the estrogen receptor through phosphorylation by mitogen-activated protein kinase. Science 270 1491-1494. (doi:10.1126/science.270.5241.1491)

Kleinberg DL \& Ruan W 2008 IGF-I, GH, and sex steroid effects in normal mammary gland development. Journal of Mammary Gland Biology and Neoplasia 13 353-360. (doi:10.1007/s10911-008-9103-7)

Kleinberg DL, Feldman M \& Ruan W 2000 IGF-I: an essential factor in terminal end bud formation and ductal morphogenesis. Journal of Mammary Gland Biology and Neoplasia 5 7-17. (doi:10.1023/A:1009507030633)

Klinge CM 2001 Estrogen receptor interaction with estrogen response elements. Nucleic Acids Research 29 2905-2919. (doi:10.1093/nar/ 29.14.2905)

Krege JH, Hodgin JB, Couse JF, Enmark E, Warner M, Mahler JF, Sar M, Korach KS, Gustafsson J-A \& Smithies O 1998 Generation and reproductive phenotypes of mice lacking estrogen receptor $\beta$. PNAS 95 15677-15682. (doi:10.1073/pnas.95.26.15677)

Lee AV, Jackson JG, Gooch JL, Hilsenbeck SG, Coronado-Heinsohn E, Osborne CK \& Yee D 1999 Enhancement of insulin-like growth factor signaling in human breast cancer: estrogen regulation of insulin receptor substrate-1 expression in vitro and in vivo. Molecular Endocrinology $\mathbf{1 3}$ 787-796. (doi:10.1210/me.13.5.787)

Lindberg MK, Moverare S, Skrtic S, Gao H, Dahlman-Wright K, Gustafsson J-A \& Ohlsson C 2003 Estrogen receptor (ER)- $\beta$ reduces ER $\alpha$-regulated gene transcription, supporting a "Ying Yang" relationship between ER $\alpha$ and ER $\beta$ in mice. Molecular Endocrinology 17 203-208. (doi:10.1210/me. 2002-0206)

Liu M-M, Albanese C, Anderson CM, Hilty K, Webb P, Uht RM, Price RH Jr, Pestell RG \& Kushner PJ 2002 Opposing action of estrogen receptors $\alpha$ and $\beta$ on cyclin D1 gene expression. Journal of Biological Chemistry 277 24353-24360. (doi:10.1074/jbc.M201829200)

Maor S, Mayer D, Yarden RI, Lee AV, Sarfstein R, Werner H \& Papa MZ 2006 Estrogen receptor regulates insulin-like growth factor-I receptor gene expression in breast tumor cells: involvement of transcription factor Sp1. Journal of Endocrinology 191 605-612. (doi:10.1677/joe.1.07016)

Matthews J \& Gustafsson J-A 2003 Estrogen signaling: a subtle balance between ER $\alpha$ and ER $\beta$. Molecular Interventions 3 281-292. (doi:10.1124/ mi.3.5.281)

Paech K, Webb P, Kuiper GGJM, Nilsson S, Gustafsson J-A, Kushner PJ \& Scanlan TS 1997 Differential ligand activation of estrogen receptors ER $\alpha$ and ER $\beta$ at AP1 sites. Science 277 1508-1510. (doi:10.1126/science.277. 5331.1508)

Pedram A, Razandi M \& Levin ER 2006 Nature of functional estrogen receptors at the plasma membrane. Molecular Endocrinology 20 1996-2009. (doi:10.1210/me.2005-0525)

Pettersson K, Delaunay F \& Gustafsson J-A 2000 Estrogen receptor $\beta$ acts as a dominant regulator of estrogen signaling. Oncogene 19 4970-4978. (doi:10. 1038/sj.onc.1203828)

Razandi M, Pedram A, Greene GL \& Levin ER 1999 Cell membrane and nuclear estrogen receptors (ERs) originate from a single transcript: studies of $\mathrm{ER} \alpha$ and $\mathrm{ER} \beta$ expressed in Chinese hamster ovary cells. Molecular Endocrinology 13 307-319. (doi:10.1210/me.13.2.307)

Razandi M, Pedram A, Merchenthaler I, Greene GL \& Levin ER 2004 Plasma membrane estrogen receptors exist and functions as dimers. Molecular Endocrinology 18 2854-2865. (doi:10.1210/me.2004-0115)

Roger P, Sahla ME, Makela S, Gustafsson J-A, Baldet P \& Rochefort H 2001 Decreased expression of estrogen receptor $\beta$ protein in proliferative preinvasive mammary tumors. Cancer Research 61 2537-2541.

Santen R, Song RX, McPherson R, Kumar R, Adam L, Jeng M-H \& Yue W 2002 The role of mitogen-activated protein (MAP) kinase in breast cancer. Journal of Steroid Biochemistry and Molecular Biology 80 239-256. (doi:10. 1016/S0960-0760(01)00189-3)

Saville B, Poukka H, Wormke M, Janne OA, Palvimo JJ, Stoner M, Samudio I $\&$ Safe S 2002 Cooperative coactivation of estrogen receptor $\alpha$ in ZR-75 human breast cancer cells by SNURF and TATA-binding protein. Journal of Biological Chemistry 277 2485-2497. (doi:10.1074/jbc.M109021200) 
Schutte B, Henfling M, Kolgen W, Bouman M, Meex S, Leers MPG, Nap M, Bjorklund V, Bjorklund P, Bjorklund B et al. 2004 Keratin 8/18 breakdown and reorganization during apoptosis. Experimental Cell Research 297 11-26. (doi:10.1016/j.yexcr.2004.02.019)

Sisci D \& Surmacz E 2007 Crosstalk between IGF signaling and steroid hormone receptors in breast cancer. Current Pharmaceutical Design $\mathbf{1 3}$ 705-717. (doi:10.2174/138161207780249182)

Song XR, Barnes CJ, Zhang Z, Bao Y, Kumar R \& Santen R 2004 The role of Shc and insulin-like growth factor 1 receptor in mediating the translocation of estrogen receptor $\alpha$ to the plasma membrane. PNAS 101 2076-2081. (doi:10.1073/pnas.0308334100)

Song RX-D, Zhang Z, Chen Y, Bao Y \& Santen RJ 2007 Estrogen signaling via a linear pathway involving insulin-like growth factor I receptor, matrix metalloproteinases, and epidermal growth factor receptor to activate mitogen-activated protein kinase in MCF-7 breast cancer cells. Endocrinology 148 4091-4101. (doi:10.1210/en.2007-0240)

Song RX-D, Chen Y, Zhang Z, Bao Y, Yue W, Wang J-P, Fan P \& Santen RJ 2010 Estrogen utilization of IGF-1-R and EGF-R to signal in breast cancer cells. Journal of Steroid Biochemistry and Molecular Biology 118 219-230. (doi:10.1016/j.jsbmb.2009.09.018)

Stewart AJ, Johnson MD, May JEB \& Westley BR 1990 Role of insulin-like growth factors and the type I insulin-like growth factor receptor in the estrogen-stimulated proliferation of human breast cancer cells. Journal of Biological Chemistry 265 21172-21178.

Thordarson G, Lee AV, McCarty M, Van Horn K, Chu O, Chou Y-C, Yang J, Guzman RC, Nandi S \& Talamantes F 2001 Growth and characterization of $\mathrm{N}$-methyl- $\mathrm{N}$-nitrosourea-induced mammary tumors in intact and ovariectomized rats. Carcinogenesis 22 2039-2047. (doi:10.1093/carcin/22. 12.2039)

Thordarson G, Semaan S, Low C, Ochoa D, Leong H, Rajkumar L, Guzman RC, Nandi S \& Talamantes F 2004a Mammary tumorigenesis in growth hormone deficient spontaneous dwarf rats; effects on hormonal treatments. Breast Cancer Research and Treatment 87 277-290. (doi:10.1007/ s10549-004-9504-2)

Thordarson G, Slusher N, Leong H, Ochoa D, Rajkumar L, Guzman R, Nandi S \& Talamantes F $2004 b$ Insulin-like growth factor (IGF)-I obliterates the pregnancy-associated protection against mammary carcinogenesis in rats: evidence that IGF-I enhances cancer progression through estrogen receptor-alpha activation via the mitogen-activated protein kinase pathway. Breast Cancer Research 6 R423-R436. (doi:10.1186/bcr812)

Ullrich A, Gray A, Tam AW, Yang-Feng T, Tsubokawa M, Collins C, Henzel W, Bon TL, Kathuria S, Chen E et al. 1986 Insulin-like growth factor I receptor primary structure: comparison with insulin receptor suggests structural determinants that define functional specificity. $E M B O$ Journal 5 2503-2512.

Xia Z, Dickens M, Raingeaud J, Davis RJ \& Greenberg ME 1995 Opposing effects of ERK and JNK-p38 MAP kinases on apoptosis. Science $\mathbf{2 7 0}$ 1326-1331. (doi:10.1126/science.270.5240.1326)

Zhao C, Matthews J, Tujague M, Wan J, Strom A, Toresson G, Lam EW-F, Cheng G, Gustafsson J-A \& Dahlman-Wright K 2007 Estrogen receptor $\beta 2$ negatively regulates the transactivation of estrogen receptor $\alpha$ in human breast cancer cells. Cancer Research 67 3955-3962. (doi:10.1158/00085472.CAN-06-3505)

Zhao C, Dahlman-Wright K \& Gustafsson J-A 2008 Estrogen receptor $\beta$ : an overview and update. Nuclear Receptor Signaling 6 e003. (doi:10.1621/nrs.06003)

Received in final form 19 October 2010

Accepted 25 October 2010

Made available online as an Accepted Preprint 25 October 2010 